Editorial

\title{
Publications: A Journal Marking a Changing Time
}

\author{
John J. Regazzi
}

Scholarly Communications and Information Innovation Lab, Long Island University, Brookville, NY 11552, USA; E-Mail: john.regazzi@liu.edu

Received: 6 December 2012/ Accepted: 11 December 2012 / Published: 12 December 2012

\section{Whither Publications?}

Publishing, and by extension publication, is in a state of rapid flux. This has become evident in recent years, and some have now even characterized the domain as unstable, with the traditional forms of publication no longer being sustainable.

The focus of Publications is to understand the drivers of these changes, and to provide some insight into their value and direction. Is technology enhancing or destroying content? Will new business models move the industry to a more value rich environment, or bankrupt our cherished traditions? Can we create "value-added" content services, or is information to become as fungible as coffee, gold and other such commodities. Will the pace of change continue, even out, or accelerate even more?

A recent report, entitled Content Disruptors, commissioned by the UK Trade and Investment (UKTI) agency and written by the Economist Intelligence Unit (EIU) [1], illustrates how much the information industry has changed and how these shifts are small in comparison to what industry experts expect still to come. It was not long ago when many thought "content is king" in a rapidly changing digital world. It turns out that this view was wrong, at least in the sense that many traditional publishing companies have found it difficult, if not impossible, to translate their intellectual property assets into dominant, leading market positions. As Encyclopedia Britannica fades, Wikipedia rises; indeed many of the powerhouses of the information, media, and entertainment industry must reconcile the likes of Google, Apple, and Facebook competing for their customers attention - and often winning the battle for mindshare. Hundreds of industry experts were surveyed and their consensus and directions were stunning; these include:

1. Digital is the single greatest area of growth, but most information companies are searching for the right strategy;

2. The industry is not sustainable in its present form - distribution channels and business models need to be revamped; 
3. Personalized data, hailed only a few years ago, is now being overtaken by "gamification" with the emphasis on interactivity and mobility, and illustrating just how fast the technology is moving.

\section{The Economics of Academic Library Spending-A Contrarian Trend or Not?}

One of the biggest consumers of publications has been libraries, particularly academic libraries. Over the last decade, the role that academic libraries played as a repository of knowledge has come under tremendous economic and technological challenges. No longer are academic libraries focused on their traditional mission of being a supporting institution to other academic units. Rather, they are undergoing a transformation to adapt to the changing university campus landscape and, in certain situations, aiming to become the center of scholarly communications. What effect has these trends taken on their content spending? It turns out that this picture is equally cloudy, as academic libraries cannot be treated as a homogeneous group. In a study by Regazzi [2], it was found that academic librarians and administrators as a group may indeed feel constrained by budget; but, over the study period of 1998-2008, academic libraries' expenditures have grown in real dollars by nearly $12 \%$ above inflation; their professional staffs have grown by nearly $15 \%$, and funding for these staffs have increased by over $22 \%$. In addition, their collections have been expanded by over $23 \%$ in current dollar funding, and serial and e-book collections have delivered dramatic value as indicated by reductions in per-unit costs. What also seems clear is that academic libraries cannot be treated as a singular group of institutions and that the drivers of the growth in this community come from the large, doctoral, private institutions; these libraries are far outpacing the growth of the group as a whole, particularly the investments that small, masters and baccalaureate, and public institutions can sustain.

Finally, it is clear from the data available that libraries are generating strong returns in their investments in electronic resources - in particular, e-books and e-serials, which are part of the digital libraries now available in the market-place. Libraries and their institutions have benefitted from these electronic materials acquisitions as measured by reductions in per-unit costs. Though total acquisition costs of e-books and e-serials have increased by $261 \%$ and $507 \%$ respectively, a $79 \%$ decrease in ebook per-unit costs and an $87 \%$ decrease in per-unit serial subscriptions have been realized across all libraries in the period 1998-2008. Libraries generally, particularly large academic libraries, continue to increase their spending on publications, while receiving excellent value for these investments.

However in another study, looking at the relative growth of a wider range on public institutions, Regazzi [3] found a different view of the academic library and its place in our modern information technology driven economy. This study compared the overall spending trends and patterns of growth in the period of 1998 to 2008 of Academic Libraries with Public Libraries, K-12 schools, higher education institutions, and hospitals. Academic Libraries, while showing growth of $13 \%$ over inflation for the period, far underperformed the growth of the other public institutions in the study. Academic Libraries lost nearly $25 \%$ of their share of higher education total spend, suggesting a shift in higher education priorities. Academic and Public Libraries are shown to have very different investment and spending priorities with Academic Libraries as a group reducing staff and investing in their collections, while Public Libraries have expanded their staff and services significantly, but not collections. Patterns of spend and investment differ markedly for Academic Libraries by size of 
institution, while size of library or community is not a differentiating determinant for staff or services growth.

As this is a complex funding environment, it is difficult and unwise to draw more conclusions from this preliminary study. There are, however, at least two fundamental questions that will undoubtedly be discussed by academic and university administrators as well as public library and funding executives going forward. These are broadly: are the current strategic directions of libraries sustainable, and are these strategies receiving adequate resourcing.

What is clear from this study is that academic libraries are pursuing a very different strategic direction then public libraries. While academic libraries continue to invest heavily in collection development, albeit moving decisively to electronic collections, public libraries are transitioning their investments from collections per se to community programs and services. Public libraries have been rewarded for this direction with a growth of $35 \%$, or more than 2.5 times that of academic libraries, over the period. Academic libraries have grown less and decreased in proportion with their parent university institutions.

On the question of sustainability and adequacy of funding, again we see two very different pictures. Public libraries, at the beginning of the great recession in 2008, received an over funding of revenues to expenses for the year as a group. Moreover public libraries outpaced academic libraries in increased spending in every category of expense, except collection expenditures, and public libraries did not reduce expenditures in any of the expense categories of their library operations. Academic libraries, on the other hand, reduced their expenditures on total staffing and overall operations; the only exception to this was in the case of large academic libraries. As a result, while all but a few public libraries grew their staffs and collections, only large academic libraries were able to grow in both dimensions, with very small and small academic libraries being affected the most adversely and finding themselves needing to reduce both their staffs and their collection development programs.

Though it will require much more analysis and study, it does seem from this initial set of findings that academic libraries need to review their emphasis on collection development, and that very small and small academic libraries in particular, will need to find a more sustainable financial footing going forward.

\section{Where Do We Go from Here?}

What do we make of these confounding and perhaps conflicting trends - industry experts proclaiming the unsustainability of our current forms of print and digital publications, while large academic libraries embrace these publications with increasingly larger and larger investments, again while other public institutions experiment with other information and service priorities. I hope that Publications, through its contributors and authors, will look at this complex field and help us begin to make sense of it direction and sustainability.

\section{References}

1. Content Disruptors. United Kingdom Office of Trade and Innovation: London, UK, 2012. Available online: http://www.ukti.gov.uk/uktihome/aboutukti/item/376220.html (accessed on 11 December 2012). 
2. Regazzi, J.J. Constrained?-An analysis of U.S. Academic Libraries and shifts in spending, staffing, and utilization, 1998-2008. Coll. Res. Libr. 2012, 73, 449-468.

3. Regazzi, J.J. Comparing Academic Library spending with Public Libraries, Public K-12 Schools, Higher Education Public Institutions, and Public Hospitals between 1998-2008. J. Acad. Librariansh. 2012, 38, 205-216.

(C) 2013 by the authors; licensee MDPI, Basel, Switzerland. This article is an open access article distributed under the terms and conditions of the Creative Commons Attribution license (http://creativecommons.org/licenses/by/3.0/). 